MARINE MAMMAL SCIENCE, 13(3):487-495 (July 1997)

(C) 1997 by the Society for Marine Mammalogy

\title{
IDENTIFYING BEAKED WHALES (FAMILY ZIPHIIDAE) USING mtDNA SEQUENCES
}

The primary characteristics used to identify beaked whale (family Ziphiidae) species (head shape, skull morphology, and location and shape of teeth) are difficult to interpret in the field, and positive identifications may require detailed examination of the head in the laboratory (Balcomb 1989; Heyning 1989; Mead 1989a,b,c). Although beaked whales have been observed entangled in the gear of fisheries around the world (e.g., Leatherwood and Reeves 1989, Watanabe 1994, Lien 1994, Julian 1996), the difficulty of identification has precluded accurate assessments of the impact of fishery mortality on populations by species. In part, this is because the collection of heads from specimens entangled in fishing gear is generally not possible due to the large size of these animals, which are often encountered by small fishing vessels. Fortunately, the ability to easily sequence species-specific DNA patterns enables species identifications to be made from just small samples of easily collected and preserved tissue (Baker and Palumbi 1994). In this note we present mitachondrial DNA (mtDNA) control region reference sequences for 10 species belonging to the family Ziphiidae and use these to make species identifications for beaked whales incidentally taken in the California drift gillnet fishery (Hanan et al. 1993). We also provide the oligonucleotide primers we developed for the polymerase chain reaction (PCR) and for sequencing a portion of the mtDNA control region of these species.

Although other regions of the mtDNA molecule have been sequenced for beaked whales (Milinkovitch et al. 1994, Árnason and Gullberg 1996), effective primers have not been available for the control region, which has been shown to be effective for species identification of cetaceans (Baker and Palumbi 1994, Dizon et al. 1996). Using primers from Rosel et al. (1994) and established protocols for DNA purification, PCR, and sequencing (Palumbi et al. 1991, Saiki et al. 1988), we were able to obtain marginal sequences of the control region for three species: Mesoplodon bidens, M. carlbubbsi, and Zipbius cavirostris. Using these sequences, we were able to identify two conserved regions, one in the tRNA proline gene and the other within the control region itself, and develop the necessary primers for PCR and sequencing. The two new primers are L15867 (5'-TCA CCA YCA RCA CCM AAA GCT GA-3') and H16329 (5'-ATG GCC CTG AAG GTA AGA ACC-3'). The numbers in the names we have given these primers correspond to the position of the $3^{\prime}$ base of the oligonucleotide in the reference sequence for a fin whale specimen published by Árnason et al. (1991a). The new primer, H16329, is a modification of H16498 published in Rosel et al. (1994). Using the two new primers and primer H0034 (Rosel et al. 1994), we were able to sequence 352- 
364 base pairs of both strands at the $5^{\prime}$ end of the mtDNA control region. All sequencing was done on an Applied Biosystems Inc. (ABI) 370A Automated DNA Sequencer with the 373 DNA Sequencing System software. Complementary strands were compared using the SeqEd DNA Sequence Editor (version $1.0 .3 ; \mathrm{ABI}$ ). Alignment of sequences was done by eye.

We obtained tissue samples from 19 individuals of 10 beaked whale species. For each specimen the identification was confirmed on the basis of skull morphology; these specimens provided our reference sequences for species identification. The species represented in this catalog include all those known to occur in the North Pacific except $M$. ginkgodens, and all those known to occur in the North Atlantic except Hyperoodon ampullatus and $M$. grayi (Balcomb 1989; Heyning 1989; Mead 1989a,b). Our only representative from southern oceans was Tasmacetus shepherdi (Mead 1989c). All reference sequences are available through GenBank (Table 1).

Since 1990, fishery observers have been placed aboard California drift gillnet vessels to record bycatch data for estimating mortality by species (Julian 1996, Julian and Beeson 1997) and to collect biological samples for determining age and sex selectivity of the gear (Chivers et al. 1996). Among the samples collected by drift gillnet fishery observers (see Jefferson et al. 1994 for sampling protocol) were 12 which had field identifications indicating a species belonging to the family Ziphiidae. They include six specimens of $Z$. cavirostris, one of Berardius bairdii, and five unidentified ziphiids. Besides $Z$. cavirostris and $B$. bairdii, five species of mesoplodont beaked whales: $M$. densirostris, $M$. stejnegeri, $M$. bectori, $M$. ginkgodens, and $M$. carlbubbsi have been recorded off the coast of California (Balcomb 1989, Heyning 1989, Mead 1989a). The distribution of these species is not well known, and therefore all of them had to be considered when evaluating the five unknown samples.

Species identifications using mtDNA sequences were based on evaluating only the number of homologous inter- and intraspecific base-pair differences in pairwise comparisons of sequences. A total of 11 gaps were used to align the data set prior to making these comparisons. Transitions and transversions were weighted equally, and gaps were not scored. In out reference collection we had nine samples of $Z$. cavirostris from three geographic areas: the California coastal area, the Central Pacific (Johnston Atoll), and the Gulf of Mexico. Within this series the number of base-pair differences ranged from zero to seven. The number of base-pair differences in pairwise comparisons berween the $Z$. cavirostris sequences and all other confirmed reference sequences of other ziphiid species ranged from 25 to 41 . For the four $M$. bidens samples (one from Florida and three from the western North Atlantic), the number of basepair differences ranged from zero to one base, while interspecific pairwise comparisons ranged from 14 to 41 bases. Thus, we have confirmation that the interspecific differences are.considerably larger (i.e., 14-45 base pairs) than intraspecific differences (i.e., $0-7$ base pairs) for the ziphiid species we have examined (Table 2).

Based on this examination of our reference sequences, we provisionally considered $\leq 10$ base-pair differences between pairs of sequences to indicate a 
Table 1. The specimens used to generate reference sequences are listed for each ziphiid species available. The "Catalog \#" is the accession number assigned by the Southwest Fisheries Science Center when the sample is received; all codes begin with a "z." The "Field \#" is the identification number assigned either in the field by the collector of the specimen or in the laboratory by the institution which archived and subsequently supplied the specimen to us. All sequences for these samples with confirmed species identifications have been submitted to GenBank, and the accession number is listed for each sequence.

\begin{tabular}{|c|c|c|c|c|}
\hline Catalog \# & Field \# & Species & Institution & $\begin{array}{l}\text { Accession } \\
\text { or number }\end{array}$ \\
\hline 24965 & LACM86031 & Berardius bairdii & Natural History Museum of Los Angeles County & $\mathrm{U} 70467$ \\
\hline $\mathrm{z} 4963$ & LACM86029 & B. bairdii & Natural History Museum of Los Angeles County & $\mathrm{U} 70468$ \\
\hline 220 & RKB1342 & Mesoplodon bidens & U.S. Fish and Wildlife Service, Gainesville, FL & U70456 \\
\hline $\mathrm{z} 3854$ & D-00253 & M. bidens & NMFS/Northeast Fisheries Science Center (NEFSC) & $\mathrm{U} 70457$ \\
\hline z3858 & D-01380 & M. bidens & NMFS/NEFSC & U70458 \\
\hline 23859 & C9D-906149 & M. bidens & NMFS/NEFSC & U70459 \\
\hline 273 & LACM84043 & M. carlbubbsi & Natural History Museum of Los Angeles County & U70461 \\
\hline 24010 & $\mathrm{~N} / \mathrm{A}$ & M. densirostris & NMFS/Southwest Fisheries Science Center (SWFSC) & $\mathrm{U} 70464$ \\
\hline$z 2698$ & $5-94-\mathrm{Me}-06$ & M. eturopaetus & Marineland of Florida & $\mathrm{U} 70460$ \\
\hline$z 4976$ & USNM 504259 & $M$. bectori & Smithsonian Institution, Washington, D.C. & $\mathrm{U} 70466$ \\
\hline $\mathrm{z} 4968$ & USNM504724 & M. mints & Smithsonian Institution, Washington, D.C. & $\mathrm{U} 70465$ \\
\hline 24959 & AF4245 & M. stejnegeri & University of Alaska, Fairbanks & $\mathrm{U} 70462$ \\
\hline$z 4962$ & LACM84299 & $M$. stejnegeri & Natural History Museum of Los Angeles County & U70463 \\
\hline z3035 & $\mathrm{N} / \mathrm{A}$ & Ziphius cavirostris & Texas Marine Mammal Stranding Network & U70455 \\
\hline 24967 & LACM91909 & $Z$. cavirostris & Natural History Museum of Los Angeles County & $\mathrm{U} 70452$ \\
\hline 24961 & LACM84111 & Z. cavirostris & Natural History Museum of Los Angeles County & U70454 \\
\hline 21120 & MGK0061 & $Z$. cavirostris & NMFS/SWFSC & $U 70453$ \\
\hline$z 4971$ & USNM484878 & Tasmacetus sbepberdi & Smithsonian Institution, Washington, D.C. & U70469 \\
\hline
\end{tabular}


Table 2. Distance matrix of the absolute number of base-pair differences, excluding gaps, for all pairwise comparisons of the ziphiid specimen data set. Species names and Southwest Fisheries Science Center archival number (" $z$ " number) are printed in bold for all reference sequences. Cells in parentheses show intraspecific differences between reference sequences. Also, numbers 25 and 28 each represent two identical reference sequences. The specimen samples collected by fisheries observers are $1-6,11-14$, and 23 . Specimen 24 is a sample collected from a stranding in Alaska which was mistakenly identified in the field as $B$. bairdii and therefore is not listed in bold. The codes listed in place of species names for fishery collected specimens are two categories of unidentified beaked whale species used by observers in the field: ZU for "Unidentified ziphiid" and UM for "Unidentified mesoplodont."

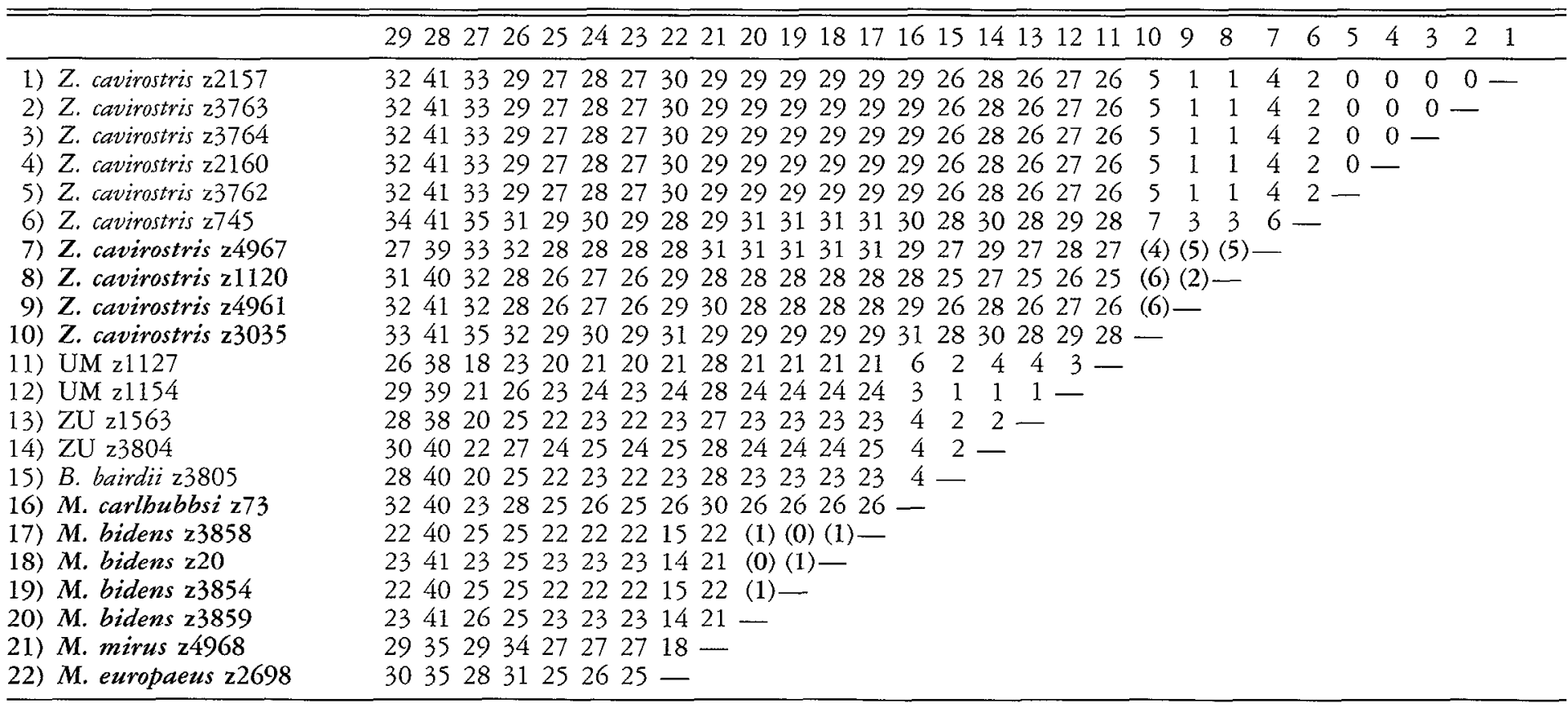


Table 2. Continued.

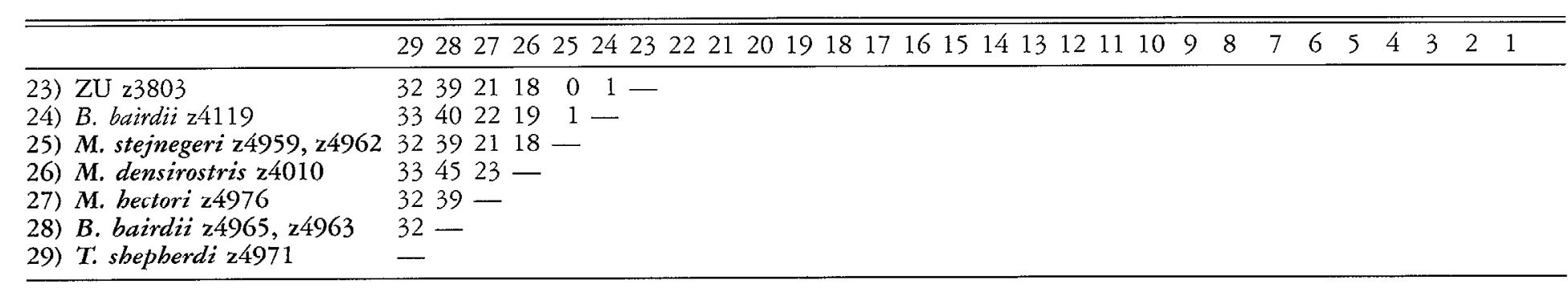


positive species identification. We would caution though that this criterion will likely depend on the family of species being examined and may have to be revised when control region sequences are available for all the species in Ziphiidae. Ideally, inter- and intraspecific geographic variation should be surveyed for all species in a family with specimen material collected throughout their range to create a reference catalog for identifying unknowns. The sample size needed to do this will ultimately depend on the amount of variability present in the control region for all species in a family. When a survey of variability is incomplete, there is the potential for errors in species identifications. For example, if there arc recently diverged species in a family, the sequences may differ by only a few base pairs, and a misidentification may be made. Additionally, a hybrid animal may be identified incorrectly, because mtDNA is matrilineally inherited. We assume that this possibility is of little concern, however, because of the rarity with which hybridization events occur (Árnason et al. 1991b). Notwithstanding these caveats, we feel confident that our present catalog enables us to make species identifications for all beaked whale samples, with the exception of $M$. ginkgodens, collected from California waters.

Using the criterion of $\leq 10$ base pair differences as the basis for species identification, each control-region sequence for a sample collected by a fishery observer was compared to all reference sequences and the species determined (Table 2). The species identification for the six samples identified in the field by fishery observers as $Z$, cavirostris were all confirmed. Of the five unidentified samples, four were identified from the control region sequence as $M$. carlbubbsi and one as $M$. stejnegeri. The sample which had been identified in the field as $B$. bairdii was identified as $M$. carlbubbsi.

Field identifications of $Z$. cavirostris appear to be relatively easy, based on the concordance between field and genetic species identifications. Identification of other beaked whales appears to be more difficult. For example, we show two cases in which a Mesoplodon species was misidentified in the field as $B$. bairdii, this despite the fact that cetacean biologists generally think that $B$. bairdii is readily identifiable in the field, because its head shape and adult size are quite different from those of the other beaked whale species. In one case, described above, a sample identified by a fishery observer as $B$. bairdii was four base pairs different from the reference sequence for $M$. carlbubbsi and 40 base pairs different from two reference sequences for $B$. bairdii. The second erroneously field-identified sample supposed to be $B$. bairdii was sent to us from a stranding in Alaska, and no collaborative evidence (i.e., skull or photographs) was collected. The control region sequence of this sample was only one base different from two $M$. stejnegeri reference sequences and 39 bases different from the two $B$. bairdii reference sequences (Table 2). Clearly, identification of beaked whales can be difficult in the field even when the specimen is in hand.

This difficulty in making reliable species identifications in the field for beaked whales has resulted in the development of management plans for $U$. S. Pacific waters that recognize just three management units: $B$. bairalii, $Z$. 
cavirostris, and mesoplodont beaked whales (Mesoplodon spp.) (Barlow et al. 1995a). All three groups are considered "strategic stocks," as defined under the current guidelines for implementation of the Marine Mammal Protection Act, because estimates of incidental fishery mortality exceed the "potential biological removal" (PBR) estimates for each management unit (Barlow et al. 19956). Although the PBRs are likely to be underestimated, because surveybased population estimates for beaked whales are biased downward due to their long dive times and short surface intervals (Barlow et al. 19956), the mortality estimates may also be in error as a result of incorrect species identifications made in the field. Our identifications have provided confirmation of only two Mesoplodon species, $M$. carlbubbsi and $M$. stejnegeri, which are taken incidentally by the California drift gillnet fishery and that the incidental take of beaked whales in this fishery is dominated by two species: $M$. carlbubbsi and $Z$. cavirostris. Future management plans should recognize this selectivity.

We feel confident that we can identify all species encountered in the California drift gillnet fishery to date, using control region sequences. Also, when complete with reference sequences from all species of Ziphiidae, the catalog will be useful for identifying any ziphiid species encountered in a fishery or on the beach around the world with the collection of just a small tissue sample.

\section{ACKNOWLEDGMENTS}

We are grateful to all the people who provided us with samples, but especially to the individuals who originally collected the specimen material with a view to making it available for future research. We do not know the names of all these people, but we would like to expressly thank the following for sending us samples: Nelio Barros, Sea World of Florida, Orlando, FL; Robert Bonde, U.S. Fish and Wildlife Service, Gainsville, FL; Phil Clapham, James Mead, and Charles Potter, National Museum of Natural History, Smithsonian Institution, Washington, DC; Joseph Cook, University of Alaska Museum, Hairbanks, AK; John Heyning, Natural History Museum of Los Angeles County, Los Angeles, CA; John Nicolas, Northeast Fisheries Science Center, Woods Hole, MD; and Graham Worthy, Texas Marine Mammal Stranding Network, Galveston, TX. We also thank the NOAA-NMFS observers who, with the coopcration of the vessel captains, collected samples aboard drift gillnet fishing vessels. Jim Carretta, John Heyning, Wayne Perryman, and an anonymous reviewer kindly provided comments that improved the manuscript. Although reference sequences are available in GenBank, all specimen sequences may also be obtained by requesting them directly from the senior author. Funds for this project were provided by the National Oceanic and Atmospheric Administration, National Marine Fisheries Service, Office of Protected Resources, Washington, DC.

\section{Literature Cited}

Árnason, Ú., And A. Gullberg. 1996. Cytochrome $b$ nucleotide sequences and the identification of five primary lineages of extant cetaceans. Molecular Biology and Evolution 13:407-417.

Árnason, Ú., A. Gullberg And B. Widegren. 1991a. The complete nucleotide sequence of the mitochondrial DNA of the fin whale, Balaenoptera physalus. Journal of Molecular Evolution 33:556-568.

Árnason, Ú., R. Spilliaert, A. Palsdottir and A. Árnason. 1991b. Molecular iden- 
tification of hybrids between the two largest whale species, the blue whale ( $B a$ laenoptera musculus) and the fin whale (B. physalus). Hereditas 115:183-189.

BaKer, C. S., AND S. R. PAlumbi. 1994. Which whales are hunted? A molecular approach to monitoring whaling. Science 265:1538-1539.

BALCOMB III, K. C. 1989. Baird's beaked whale, Berardius bairdii Stejneger, 1883: Arnoux's beaked whale, Berardius arnuxii Duvernoy, 1851. Pages 261-288 in S. H. Ridgway and R. J. Harrison, eds. Handbook of marine mammals, Vol. 4. Academic Press, London, U.K.

Barlow, J., S. L. Swartz, T. C. EAgle and P. R. Wade. 1995a. U.S. marine mammal stock assessments: Guidelines for preparation, background, and a summary of the 1995 assessments. U.S. Department of Commerce, NOAA Technical Memorandum NMFS-OPR-6. 73 pp.

Barlow, J., R. J. Brownell, Jr., D. P. DeMaster, K. A. Forney, M. S. Lowry, S. Osmek, T. J. Ragen, R. R. Reeves and R. J. Small. 19956. U.S. Pacific marine mammal stock assessments. U.S. Department of Commerce, NOAA Technical Memorandum NMFS-SWFSC-219. 162 pp.

Chivers, S. J., K. M. Robertson and M. D. Henshaw. 1997. Composition of the incidental kill of cetaceans in two California gillnet fisheries: 1990-1995. Report of the International Whaling Commission 48:(in press).

Dizon, A. E., C. A. Lux, R. G. LeDuc, J. Urban R., M. D. Henshaw, C. S. Baker, F. Cipriano and R. L. Brownell, JR. 1996. Molecular phylogeny of the Bryde's/ sei whale complex: Separate species status for the pygmy Bryde's form? Paper $\mathrm{SC} / 48 / 027$ presented to the International Whaling Commission Scientific Committee, June 1996 (unpublished). International Whaling Commission, Station Road, Histon, Cambridge CB4 4NP, U.K.

Hanan, D. A., D. B. Holts and A. L. Coan, Jr. 1993. The California drift net fishery for sharks and swordfish, 1981-82 through 1990-91. California Departrnent of Fish and Game Bulletin 175:1-95.

Heyning, J. E. 1989. Cuvier's beaked whale, Zipbius cavirostris G. Cuvier, 1823. Pages 289-308 in S. H. Ridgway and R. J. Harrison, eds. Handbook of marine mammals, Vol. 4. Academic Press, London, U.K.

Jefrerson, T. A., A. C. Myrick And S. J. Chivers, 1994. Small cetacean dissection and sampling: A field guide. U.S. Department of Commerce, NOAA Technical Memotandum NMFS.SWFSC-198. 54 PP.

Julian, F. 1996. Cetacean mortality in California gillnet fisheries: Preliminary estimates for 1995. Paper SC/481/SM 11 presented to the International Whaling Commission Scientific Committee, June 1996 (unpublished). International Whaling Commission, Station Road, Histon, Cambridge CB4 4NP, U.K.

Julian, F., ANd M. BeEson. 1997. Estimates of mammal, turtle, and bird mortality for two California gillnet fisheries: 1990-1994. Fishery Bulletin, U.S. (In press).

Leatherwood, S., AND R. Reeves. 1989. Marine mammal research and conservation in Sri Lanka 1985-1986. Nairobi, Kenya. United Nations Environment Programme Marine Mammal Technical Report Number 1. vi, 138 pp.

LIEN, J. 1994. Entrapments of large cetaceans in passive inshore fishing gear in Newfoundland and Labrador (1979-1990). Report of the International Whaling Commission (Special Issue 15):149-157.

Mead, J. G. 1989a. Beaked whales of the genus Mesoplodon. Pages 349-9430 in S. H. Ridgway and R. J. Harrison, eds. Handbook of marine mammals, Vol. 4. Academic Press, London, U.K.

Mead, J. G. 1989b. Bottlenose whales, Hyperoodon ampullatus (Forster, 1770) and Hyperoodon planifrons Flower, 1882. Pages $321-348$ in S. H. Ridgway and R. J. Harrison, eds. Handbook of marine mammals, Vol. 4. Academic Press, London, U.K.

Mead, J. G. 1989c. Shepherd's beaked whale, Tasmacetus shepherdi Olivier, 1937. Pages 
309-320 in S. H. Ridgway and R. J. Harrison, eds. Handbook of marine mammals, Vol. 4. Academic Press, London, U.K.

Milinkovitch, M. C., A. Meyer and J. R. Powell. 1994. Phylogeny of all major groups of cetaceans based on DNA sequences from three mitochondrial genes. Molecular Biology and Evolution 11:939-948.

Palumbi, S. R., A. P. Martin, S. Romero, W. O. McMillan, L. Stice and G. GrawiBOwski. 1991. The simple fool's guide to PCR version 2.0. University of Hawaii, Honolulu. 44 pp.

Rosel, P. E., A. E. Dizon And J. E. Heyning. 1994. Genetic analysis of sympatric morphotypes of common dolphins (genus Delphinus). Marine Biology 119:159167.

Saiki, R. K., D. H. Gelfand, S. Storffei, S. J. Scharf, R. Higuchi, G. T. Horn, K. B. Mulirs and H. A. Erlich. 1988. Primer-directed amplification of DNA with a thermostable DNA polymerase. Science 239:487-491.

WatANABE, Y. 1994. The Japanese large-mesh driftnet fishery in the Pacific ocean. Report of the International Whaling Commission (Special Issue 15):385-392.

Michael D. Henshaw, Richard G. LeDuc, Susan J. Chivers, and Andrew E. Dizon, National Marine Fisheries Service, Southwest Fisheries Science Center, P.O. Box 271, La Jolla, California 92038-0271, U.S.A. Received 10 July 1996. Accepted 1 August 1996. 